\title{
技術報告
}

\section{焼麩（白玉麩）の比容積におよぼすグルテンと 合わせ粉の配合の影響}

\author{
村瀬 誠* ·水谷哲也** ・杉本勝之*
}

\author{
Effect of Gluten to Flour Ratio on the Specific Volume of "Yakifu" \\ (Basic Studies on the Production of "Yakifu" Part IV) \\ Makoto Murase*, Tetsuya Mizutani* and Masayuki Sugimoto* \\ *Food Research Institute, Aichi Prefectural Government, 2-1-1, Shinpukuji-cho, \\ Nishi-ku, Nagoya-shi, Aichi 451 \\ ** Minokyuh Co, Ltd., 24-1, aza-Hongoumae, Togari, Hagiwara-cho, \\ Ichinomiya-shi, Aichi 491-03
}

\begin{abstract}
Effects of gluten (G) to flour (F) ratios of gluten-dough on the specific volumes and honey-comb structure of "Yakifu" were studied. Among the G/F ratios studied, 500/300 gave the biggest specific volume. When wheat starch (S) was submitted for flour, the biggest specific volume was attained at $\mathrm{G} / \mathrm{S}$ ratio of $450 / 350$, although the value was much smaller. At G/F ratio of $600 / 200$ or $550 / 250$, only insufficient gluten-dough could be formed, suggesting the ratio of flour was too small to form uniform structure. When defrosted gluten was baked, it gave vacant structure with glassnized membrane. This implied the important role of starch in forming honey-comb structure of expanded products. Therefore, gluten-dough needs (1) to be formed well, (2) to containe optimum amount of protein, (3) to contain optimum amount of starch and (4) to involve optimum amount of water.
\end{abstract}

(Received Feb. 15, 1996, Accepted Sep. 19, 1996)

焼趁の品質は此容皘や組織構造の均一性などで評価さ れる. 特に比容積は，同一条件で焼成した場合には配合， 原材料の品質，グルテンドウの調製方法あるいは前処理 などの影響を受けることが経験的に知られている。これ らのうち原材料についてみると，小麦粉から分離したグ ルテンと合わせ粉 (小麦粉, 強力二等粉あるいは三等粉) 之微量の膨張凧が主体である1，一方，市販の焼趃の比 容積と成分の関係について分析した結果 ${ }^{2)}$ ，比容皘が大 きい狫麩ほどタンパク質含量が高い傾向が認められた。 市販品の配合や製造方法などは明らかではないが焼趃の 膨化に関してはタンパク質の寄与が大きいことを示して
いる、タンパク質含量はグルテンと合わせ粉の比率に依 存しているので，現場では製品の種類や比容積の大小を 考虑しながら，合わせ粉を選定し，配合を決めているも のと推測される. しかし，合わせ粉の品質や配合と焼趁 の比容積との関係について科学的な解明はほとんどされ ていない，従って，製造現場においては経験と勘に基づ いた対応をしているのが実情である。そこで，本報では グルテンドウの配合と比容積との関係について，自由に

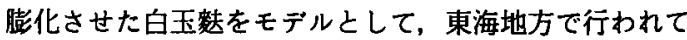
いる製造方法に準じて検討した。

†焼制の製造に関する基礎的研究（第 4 報）

* 愛知県食品工業技術センター（厂451 愛知県名古屋市西区新福寺町 2-1-1）

** 現在，(株)美/久（广491-03 愛知県一宮市萩原町戸荻字本郷前 24の 1) 
実験材料と方法

\section{1. 実験材料}

冷凍グルテン ((株)横尾商店製，水分 $68.4 \% ，$ タンパ ク質 $24.6 \%$ ，灰分 $0.23 \%$ ），強力小麦粉（セントラル製粉

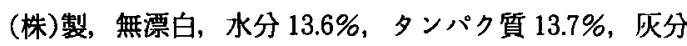
0.56\%，これを本報では合わせ粉と称する）を使用した。 粉末グルテンおよび小麦でん粉は(株)グリコ栄養食品製

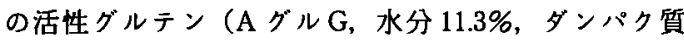
$70.9 \%$ ，灰分 $0.36 \%$ ）および食品用でん㸮（マルカマ印, 水分 $12.2 \%$ ，タンパク質 $0.1 \%$ ，灰分 $0.03 \%$ ）を使用し た.

\section{2. グルテンドウの調製}

前報 ${ }^{334)}$ に準じ，地引機上呼ばれる練り機（1 枚羽，回 転数 $200 \mathrm{rpm}$ ）で，均質な粘質物となるまで混練を行っ た. なお，1試験で調製するグルテンドウの量は，820 g とした．調製したグルテンドウは乾燥を防ぐためにポリ エチレン製の袋に封入し，また熟成の進行を抑制するた めに狫成するまで冷蔵庫に保管した。

（1）グルテン（G）と合わせ粉（F）の割合が異なるグ ルテンドウの調製

$\mathrm{G} / \mathrm{F}=800 / 0,700 / 100,600 / 200,550 / 250,500 / 300$, $450 / 350,400 / 400,350 / 450$ 及び $300 / 500$ とし, 水 $20 \mathrm{ml}$ を加えてグルテンドウを調製した。

（2）小麦粉の代わりに小麦でん粉（S）を使用したグ ルテンドウの調製

$\mathrm{G} / \mathrm{S}=550 / 250 ， 500 / 300 ， 450 / 350 ， 400 / 400$ 及び $350 /$ 450 とし, 水 $20 \mathrm{ml}$ を加えてグルテンドウを調製した.

（3）小麦粉の代わりに粉末グルテン（PG）を使用した グルテンドウの調製

$\mathrm{G} / \mathrm{PG}=550 / 250 ， 500 / 300 ， 450 / 350$ 及び $400 / 400$ と

し，水 $20 \mathrm{~m} l$ を加えてグルテンドウを調製した。

\section{3. 焼成方法}

焼成条件は床板温度を $200^{\circ} \mathrm{C}$, 天板温度を $230^{\circ} \mathrm{C}$ とし， $10 \mathrm{~m} l$ あるいは $20 \mathrm{~m} l$ の散水量で焼成時間は 11 分とし $た^{3)}$.

一度に焼成する種の個数としては 25〜30とした。製 品としての焼麩区別し，本報では焼成したものを膨化 物と呼ぶこととした

\section{4. 比容積の測定}

それぞれの焼成時における 25〜30 個の焼成物のうち， 平均的な形状の膨化物 10 個を任意に選択し，前報了）に 準じて植物種子置換法により测定し，その平均値を比容 皘 $(\mathrm{m} l / \mathrm{g})$ とした.

\section{5. 膨化物の物理特性の測定}

レオメータ・マックス（(株)アイテクノ製, $\mathrm{RX}-1600$ 型）により，円柱状プランジャ一（值径 $8 \mathrm{~mm}$ ）を使用 し, 圧縮速度 $300 \mathrm{~mm} / \mathrm{min}$ ，クリアランス $10 \mathrm{~mm}$ で測 定し，プランジャーが膨化物の表皮を破境して侵入する ときの荷重を破断強度 $\left(\mathrm{kg} / \mathrm{cm}^{2}\right)$ ，またその時の試料の 変形量を破断歪み $(\mathrm{cm} / \mathrm{cm})$ として計測した。

\section{6. 成分分析 ${ }^{5}$}

タンパク質の分析はセミマクロケルダール法により行 い，タンパク質換算係数は， 5.70 を適用した。水分の測 定は $105^{\circ} \mathrm{C}$ 乾燥法により行った。

\section{7. 膨化物の微細構造の観察}

前報 ${ }^{6)}$ に準じて膨化物の微細構造を観察した。

\section{実験結果および考察}

\section{1. グルテンと合わせ粉の混合割合}

グルテンと合わせ粉の混合割合 $(G / F)$ が膨化物の比 容積に与える影響について検討した（Fig. 1)，G/F＝ $500 / 300$ のとき比容積が最大の膨化物が得られた。 それ より $\mathrm{G}$ が多い550/250では比容積が小さかったが, F が 多い 450/350，400/400ではかなり大きい比容積を示し

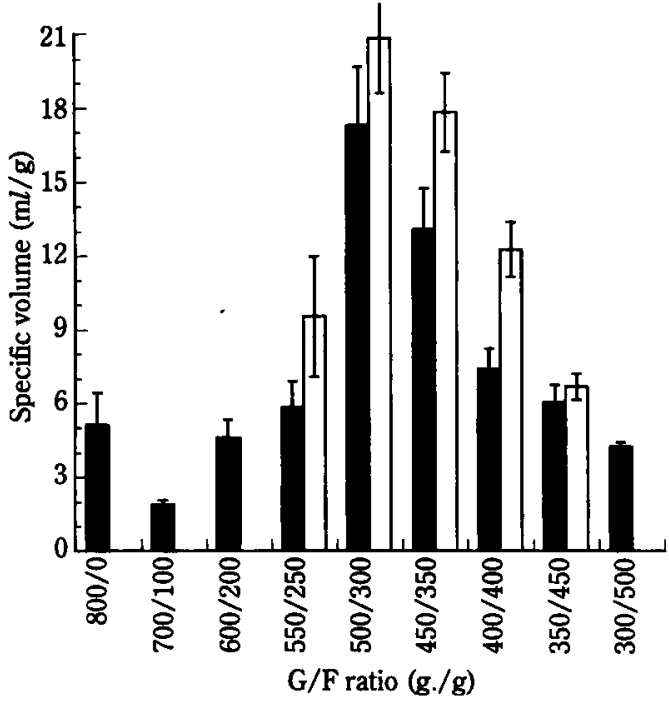

Fig. 1 Effect of $\mathrm{G} / \mathrm{F}$ ratio on the specific volume of expanded product

Defrosted gluten and flour were mixed in different ratio with "Jibikiki" for optimum periods for each mixture.

$\square$ poured water ; $10 \mathrm{ml} ; \square$ poured water ; 20 $\mathrm{m} l$ 
た. $350 / 450$ のときの比容積は $550 / 250$ の膨化物に類似 していた．このことからグルテンが膨化するためには一 定の割合の合わせ粉の存在が必要であることが明らかに なった．なお，散水量を $10 \mathrm{~m} l$ から $20 \mathrm{ml}$ に增加する効 果は $\mathrm{G} / \mathrm{F}=400 / 400$ のとき最大で，散水量 $10 \mathrm{ml}$ で大き い比容皘を示した $500 / 300$ あるいは 450/350のときは, 散水量を $20 \mathrm{ml}$ にしてもその效果は顕著でなかっだ). 散水量 $10 \mathrm{~m} l$ で膨化の限界近辺に到達しているものと推 湘された。なおな゙ルテンドウの性状は $\mathrm{G}$ が 800〜550 のときドウとしての䀥がりが不十分であり，外観，切り 口は斑で均一にならなかった。特に Gが800〜600の範 囲では手揉み法で採取する過程のグルテンの性状に近 く, 網目状の塊であったのに対して, G が500〜300では 均一で滑らかになった，すなわち，グルテンドウを調製 する場合にはつなぎとしての合わせ粉が重要な役割を果 たしていることを示す. 但し， G が 350〜300では粘弾性 に次け，さくさくしたグルテンドウであったまた，適 性混練時間4)はグルテンの割合が高いほど長くなり，G/ $\mathrm{F}=500 / 300$ では 10 分まで, 混練時間が長くなるはど比 容積が大きくなる傾向を示した。

Fig. 2 にこのときの膨化物の一部の形状を示した. G/ $\mathrm{F}=550 / 250$ (Fig. 2-A) のとき形が歪であり, 硬く重い
感じがした．表面は斑状を呈し，断面の気泡は粗く，空 洞が多く焼椊の膨化構造としては不適であった．500/ 300 (Fig. 2-B) ではふっくらとした球形を呈し, 軽くソ フトな焼き上がりであった．断面は大きく粗い蜂の单構 造が形成された. 450/350 (Fig. 2-C) では軽くソフトで 球形に焼き上がり，断面の蜂の巣構造は微細であり, 400/400 (Fig. 2-D) の場合には表面につやがなく, ソフ トな感じがなくなった，断面の蜂の巣構造は微細で, 硬 かった。なお， G/F=800/0 あるいは 700/100の場合に 得られた膨化物の内部には水が残り，この配合と焼成条 件では水の蒸散が不十分であり，膨化組織の形成も不完 全であることを示した，一方，前述したグルテンドウの 性状と併せて考えると，膨化するためには連続した，均 一なグルテンドウの形成が必須条件であることが確認さ れた.

\section{2. 小麦でん粉の影䈏}

前記の結果から，グルテンが膨化するためには適当な 割合で合わせ粉 (小麦粉) を混合する必要が確認された。 合わせ粉の役割として, (1) グルテンの水分の調整, (2) グ ルテンドゥの形成補助, (3) タンパク質の補強等が考えら れる，一方，焼成食品におけるでん粉の役割については 幾つかの報告(7) があり，組織構造の形成などにおける

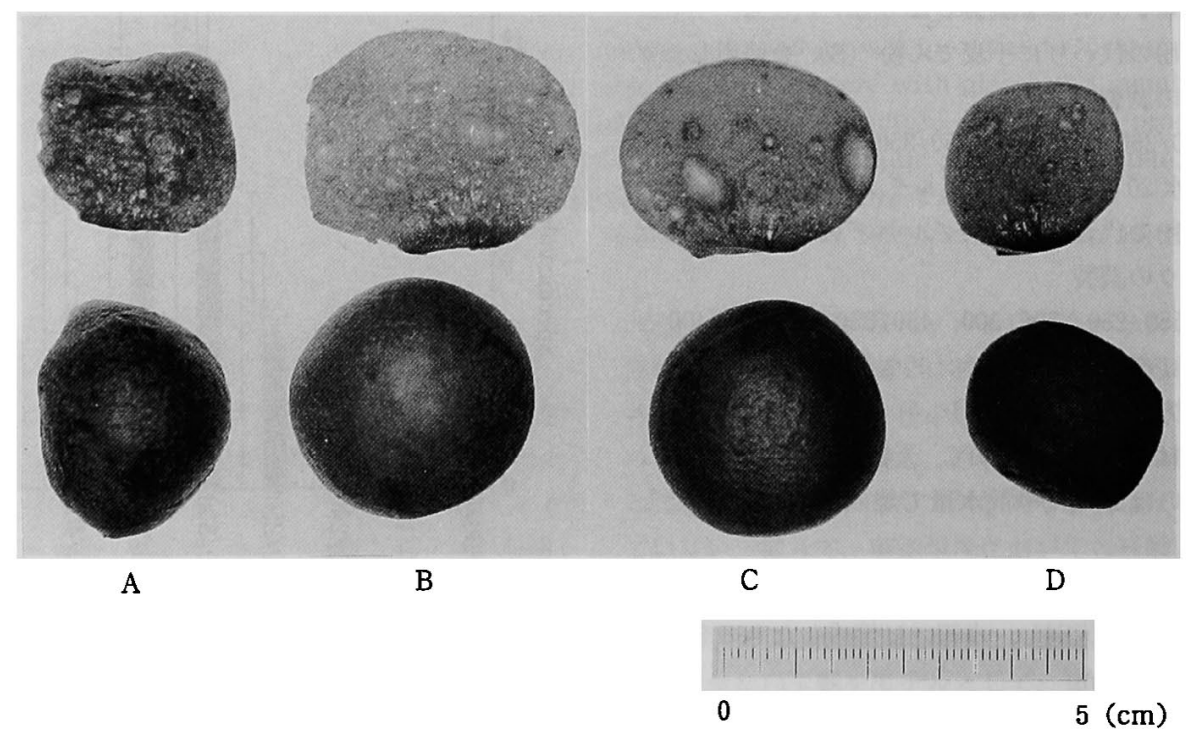

Fig. 2 Photographs of expanded products obtained by baking gluten-doughs of different $\mathrm{G} / \mathrm{F}$ ratio

G/F ratios are as follows ; A, 550/250; B, 500/300; C, 450/350 ; D, 400/400. Lower, Whole appearance ; Upper, Vertical section. 
重要な役割が示されている，そこで，合わせ粉として小 麦粉の代わりにタンパク質をほとんど含まない小麦でん

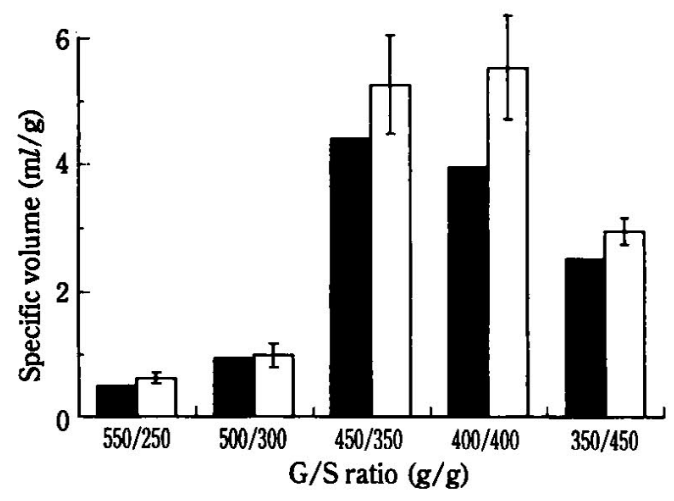

Fig. 3 Effect of G/S ratio on the specific volume of expanded product

Defrosted gluten and wheat flour were mixed in different ratio with "Jibikiki" for optimum periods for each mixture.

poured water $; 10 \mathrm{ml} ; \square$ poured water ; 20 $\mathrm{m} l$
粉を使用し, 水分調整とタンパク質含量が比容積におよ ぼす影響について検討した（Fig. 3)，小麦でん粉を使用 した場合の膨化物は合わせ粉を使用した場合に比べて小 さく, 最大の比容積が得られる配合は $\mathrm{G} / \mathrm{S}=450 / 350$ 之 なり，G/F（S）の比率はF（S）の割合が高い方へシフ トした．でん粉を使用した場合にはグルテンドウの水分 含量か膨化に影響を与え，合わせ粉の効果の一つとして 水分調整が含まれることを示す.グルテンドウの性状は 合わせ粉を使用したときのそれに類似していたが，全体 に粘弾性に欠けたものであった。このときの膨化物の形 状の一部を Fig. 4 に示した。 G/S=500/300では膨化せ ず,断面に膨化組織は認められなかった (Fig. 4-A). G/ $\mathrm{S}=450 / 350$ (Fig. 4-B) あるいは 400/400 (Fig. 4-C) に なると丸みを帯びた膨化物が得られ，断面には蜂の巣構 造が見られるようになった。一般に，でん粉が少ない配 合（Fig. 4-B）では気泡が大きく，粗いのにでん粉の割 合が多くなるほど微細な気泡が形成されるようになった (Fig. 4-D). 良好な蜂の巣構造を有する膨化物を得るた めにはでん粉の共存も必要であるが，でん粉含量が高す ぎると蜂の巣構造の形成が悪影響を受けるものと推測さ れた。なお，膨化物の形状や性状，断面の構造に関して

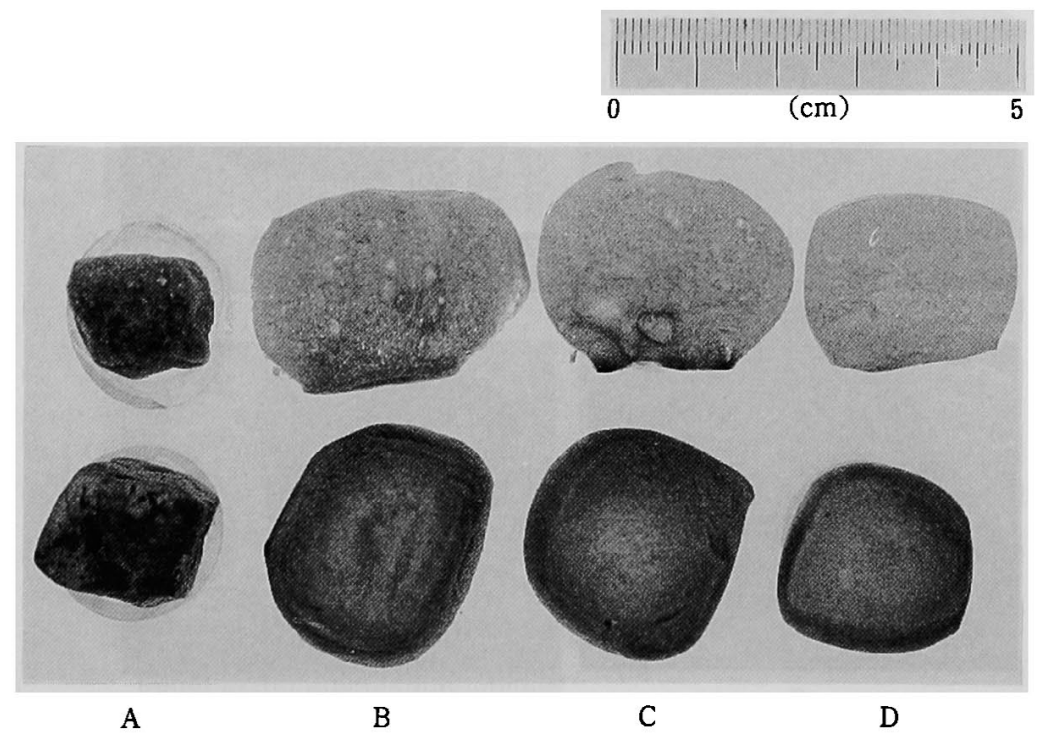

Fig. 4 Photographs of expanded products obtained by baking gluten-doughs of different $G / S$ ratio

G/S ratios are as follows ; A, 500/300 ; B, 450/350 ; C, 400/400 ; D, 350/450.

Lower, Whole appearance ; Upper, Vertical section. 
は製品の種類ごとに求められる基準があり，それを満足 するように現場では配合が決められているのであろう。

\section{3. 粉末グルテンの効果}

以上の結果から，よく膨化するグルテンドウを調製す るためには，第一に均一な組織の形成を行うことであ り, 次いでタンパク質含量が高いことが重要であること が明らかになった，小麦粉と小麦でん粉を合わせ粉とし て使用したときのグルテンドゥの水分とタンパク質含量 を比較すると，それぞれの配合のときのグルテンドウの 水分はほとんど類似しているのに対してタンパク質含量 は著しく異なる．小麦粉の割合が最も高い $\mathrm{G} / \mathrm{F}=350 /$ 450 のときグルテンドゥのタンパク質含量は約 $18 \%$ で あるのに，同じ配合で小麦でん粉を使用すると約 $11 \%$ になり，小麦粉を使用したときの $60 \%$ 程度と，合わせ粉 （小麦でん粉）の割合が高くなるとともにタンパク質含 量は低下する，以上から，合わせ粉の代わりに小麦でん
粉を使用したときに比容積が小さくなる理由はタンパク 質が不足するためであることは明らかである，そこで， 合わせ粉として粉末グルテン（PG）を使用し，グルテン ドウのタンパク質含量を高める試みを行った。いずれの 配合 $(\mathrm{G} / \mathrm{PG}=550 / 250 \sim 400 / 400)$ でも，焼成直後にはよ く膨化しているが焼成を終了すると同時に萎縮するもの が多かった．烧成時間を長く（15 分）してもその傾向は 類似していた。このことは，グルテンドウが膨化するた めにはある程度以上のタンパク質が必要であるが, 蜂の 巣構造を形成し，膨化組織を維持するためにはでん粉の 存在が不可欠であることを示す。その時の膨化物の形状 を解凍した冷凍グルテンをそのまま焼成した膨化物の形 状とともに Fig. 5 に示した，解凍したグルテンを混練す ることなく，そのまま焼成すると組織全体がガラス質化 した中空の膨化物となり，切り口はほとんど空洞で，蜂 の巣構造は認められなかった（Fig.5-A). 一方, G/PG

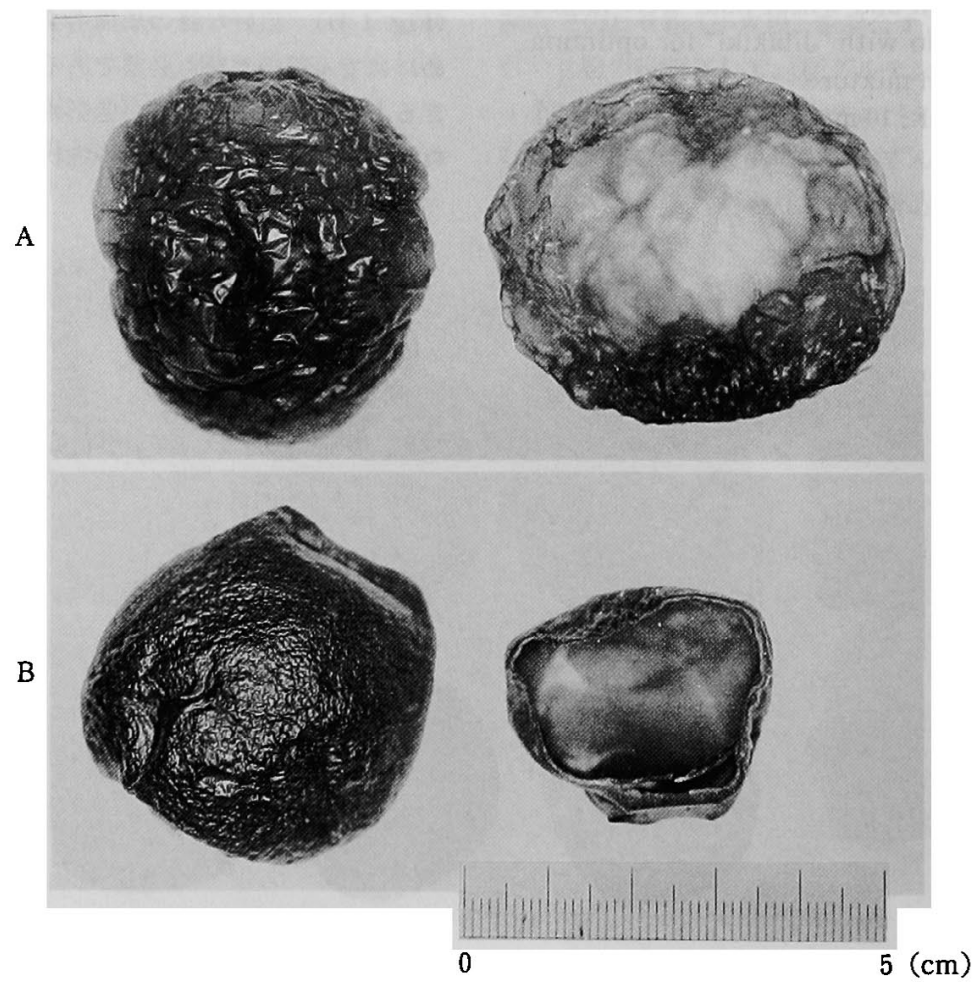

Fig. 5 Photographs of expanded products obtained by baking gluten and its mixture

A, Defrosted gluten ; B, Gluten-dough in G/PG ratio 500/300.

Left, Whole appearance ; Right, Vertical section. 
$=500 / 300$ のときの膨化物の切り口は変形したゴム鞠状 の空洞で, 蜂の巣構造の痕跡すら認められなかった (Fig. 5-B)。これら膨化物の微細構造の観察結果を Fig. 6 に示した，冷凍グルテンを解凍して焼成すると気泡の 立ち上がりは直線的で，気泡の層息を形成することなく 消失し，その先は巨大な空洞であった (Fig. 6-A). 中心 部でわずかに得られた薄膜は (Fig. 6-B) 透明感が強く, 平板ででん粉粒の残骸() は認められなかった，一方，G/

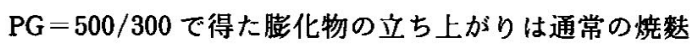
の立ち上がり構造之は根本的に異なり，むしろ萎縮した 焼匙の表皮近扨の断面構造に類似していた。すなわち， 表皮近くでは圧縮された気泡が観察され，そのすぐ内側 では表皮に向かって直角に気泡が形成されていた（Fig. 6-C). その気泡の層は 2 3 層しかなく，その内側は別 の膜で気泡の形成が制限されていた (Fig. 6-D).この結 果から，焼烤は床面から気泡の形成が始まり，順次形成 される気泡に押し上げられるようにした球形に膨化する が,でん粉が存在しない場合には気泡が固定されないた めに空洞化する. それに対して，G/PGの場合には膨化
が種の中心から始まる. 従って，床面と接触する部分で 気泡の立ち上がりが観察されないし, 気泡の圧縮が認め られる. 更に，膨化物の内部にす表皮の形成が観察され る.これらの結果からグルテンドウがよく膨化するため には, (1)グルテンと合わせ粉が十分に混練され，均一な 組織を形成すること, (2)一定の範囲のタンパク質を含む こと，(3)一定の範囲内ででん粉を含むこと，及び(4)定の範囲の水分を含むこと，の 4 点が必要であるといえ る. 特に, 膨化物の組織の形成から見ると, グルテンは 膨化，でん粉はグルテンの膨化力とガラス質化を抑制し ながら蜂の巣構造の形成に関与しているむのと推測され た. 従って,グルテンドゥの調製時に混合する合わせ粉 (小麦粉) は，(1)グルテンドゥの均質化，(2)タンパク質 の補強, 及び (3) 水分の調整の目的に使用されるむので あり，これらの目的を満足するものでなければならな w.

前述したとおり，配合を変えることにより膨化物の性 状はかなり変化するので, 今後は硬めの白玉麩想定し たときは $\mathrm{G} / \mathrm{F}=400 / 400$ (これをモデル配合 1 と呼ぶ）,

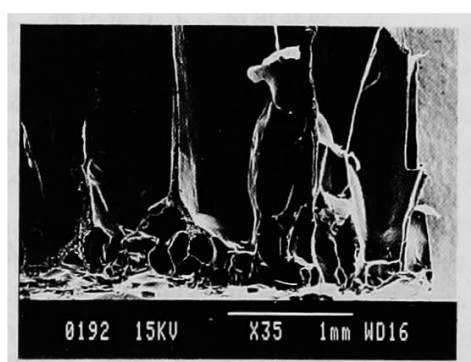

A

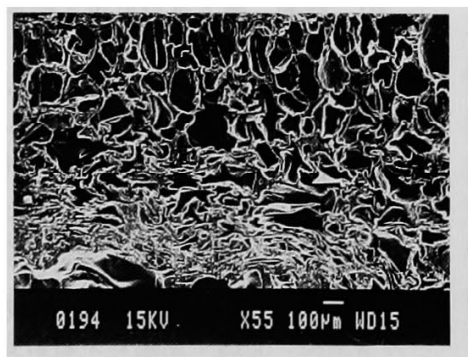

C
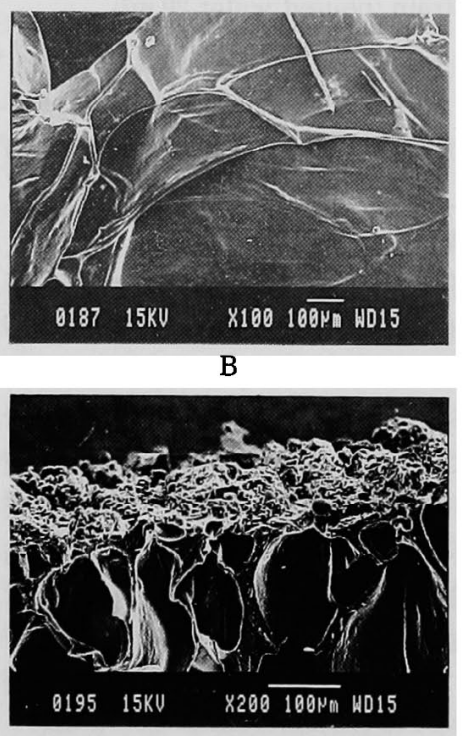

D

Fig. 6 Scanning electron microscopic observation of expanded products obtained by baking gluten and its mixture

A. Vertical section at floor of expanded product obtained from gluten : B, Membrane structure of expanded product obtained from gluten; $\mathrm{C}$, Vertical section at floor of expanded product obtained from $G / P G=500 / 300 ; D$, Vertical section and inner surface at floor of expanded product obtained from $\mathrm{G} / \mathrm{PG}=500 / 300$. 


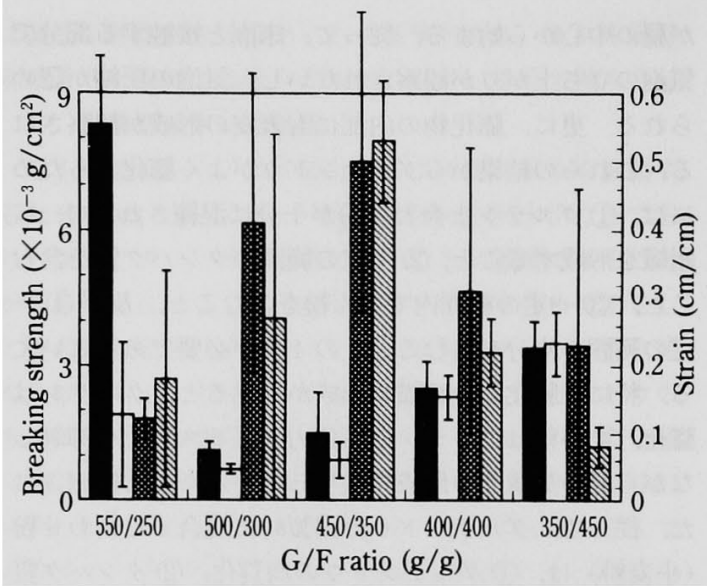

Fig. 7 Physical parameters of expanded products from gluten-doughs in different $\mathrm{G} / \mathrm{F}$ ratio

Expanded products were pressed from top to bottom with a plunger (column shaped, diameter $8 \mathrm{~mm}$ ).
Breaking strength (poured water $10 \mathrm{ml}$ ) $\square$ Breaking strength (poured water $20 \mathrm{ml}$ ) Breaking strain (poured water $10 \mathrm{ml}$ ) ; B⿺ Breaking strain (poured water $20 \mathrm{ml}$ ).

ソフトな膨化物で, 最大比容積の膨化目標を想定したと

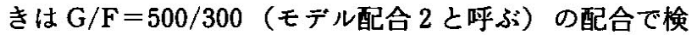
討を進めることとした。

\section{4. 膨化物の物理特性}

合わせ粉として小麦粉を使用したときの膨化物の破断 強度之破断歪みの湘定結果を Fig. 7 に示した. 比容積が 大きいほど破断強度は小さく，その時の歪みは大きく なった。ソフトでふっくらとした感触の膨化物ほど破断 時の歪みが大きいことを示し，製品の特性との関係で重 要である，例えば，圧搾麩を製造するとき，膨化物が圧

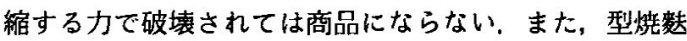
においてはその種類や形状によって硬さ, 気泡の形状に 対する要求も異なるであろう。

$$
\text { 要 約 }
$$

白玉麩をモデルとして，焼麩比容積と組織構造の形
成に及ぼすグルテンと合わせ粉の配合について検討し た. $\mathrm{G} / \mathrm{F}=500 / 300,450 / 350$ で大きい比容積の膨化物が 得られ，散水量の効果は 400/400のときに比べると小さ かった．合わせ粉として小麦でん粉を使用すると全体に 比容積は小さくなり，合わせ粉に含まれるタンパク質が グルテンドウを形成する上で重要な役割を果たすことが 明らかになった.グルテン単独では空洞化し，カラス質 化した膨化物しか得られず，合わせ粉として粉末グルテ ンを使用すると空洞化した膨化物となったことから，合 わせ粉のでん粉が焼猌特有の蜂の果構造を形成するため に重要な役割を果たしていることが推測された。なお， 膨化物の微細構造の観察結果から，粉末グルテンを合わ せ粉として使用すると膨化は中心から進行するすのと考 えられた．一方，グルテンの割合が高い膨化物は比容積 と気泡は大きく，合わせ粉の割合が高くなると比容積が 小さく，気泡が微細化し緻密になること，及び前者では 破断強度が小さく，歪みが大きく，後者では破断強度が 大きく歪みが小さくなることから，製品の種類毎に配合 を変更することの重要さが明らかになった。

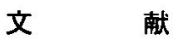

1）遠藤悦雄：小麦蛋白質一その化学と加工技術一 （食品研究社，東京）, p 104 (1955).

2）村瀬 誠・水谷哲也・杉本勝之：愛知県食品工業 技術センター年報，33，102（1992）。

3）村瀬 誠·水谷哲也・杉本勝之：食科工，43，423 (1996).

4）村瀬 誠・水谷哲也・杉本勝之：食科工，(投稿 中).

5）日本食品工業学会食品分析法編集委員会編：食品 分析法 (光琳, 東京), (1982).

6）村瀬 誠・水谷哲也・杉本勝之 : 食科工, 43,400 (1996).

7) Hoseney, R.C., Lineback, D.R. and SeiP, P.A. : Bakers Dig. 52, 11 (1978).

8) Dennett, K. and Sterling, C : Starch, 31, 209 (1979).

9) Kulp, K. and LoRenz, K. . Backers Dig., 55, 24 (1981).

（平成 8 年 2 月 15 日受付，平成 8 年 9 月 19 日受理) 